\title{
Working Capital, Financing Constraints and Firm Financial Performance in GCC Countries
}

\author{
Sree Rama Murthy Y \\ Sultan Qaboos University, Al Khod, Sultanate of Oman \\ murthy@squ.edu.om
}

\begin{abstract}
This paper looks at the impact of level of working capital on a firm's financial performance of 153 large manufacturing firms operating in the six Gulf Cooperation Council Countries (GCC).Three hypotheses being tested in the paper are that working capital levels and inventory levels have a negative impact on corporate financial performance, have a positive impact on corporate financial performance, or that there is no empirically provable relationship between working capital and inventory and financial performance. A number of control variables including firm size, gross margins, and age of the firm are used in the regression analysis, as financial performance is not purely dependent on working capital and inventory levels. Pre-tax return on assets (ROA-profit before tax divided by total assets) is used to measure corporate financial performance. Performance is strongly influenced by levels of accounts receivables; however inventory levels and payables have no impact on performance.
\end{abstract}

Keywords: Working capital, inventory, receivables, payables, GCC, firm performance, profitability

\section{Introduction}

This paper looks at the impact of level of working capital requirements on a firm's financial performance in the Gulf Cooperation Countries (GCC). The focus of the paper is on working capital requirements rather than working capital itself. An important contribution of this paper is that it is first to its kind looking at the relationship between working capital requirements and firm performance using published company data from companies operating in the Gulf Cooperation Council countries. Three hypotheses being tested in the paper are one, working capital levels have a negative impact on corporate financial performance; two, working capital levels have a positive impact on corporate financial performance; and three, there is no empirically provable relationship between working capital and financial performance. The study looks at all the three components of working capital requirements: inventory, accounts receivable and accounts payable. Past studies have indicated that firm size, market share, age of the firm, debt levels and economic growth as measured by growth in gross domestic product; have a moderating influence on the relationship between working capital and performance. In this paper a number of control variables including firm size, gross margins, and age of the firm are used in the regression analysis, as these are the primary factors which have a strong influence on financial performance and since performance is not purely dependent on working capital requirements.

Conceptual Framework: The focus of the paper is on working capital requirements rather than working capital itself. While working capital is defined as current assets minus current liabilities, working capital requirements are defined as inventory plus accounts receivables minus accounts payables. Firms require raw material, work in progress inventory and finished goods inventory to produce and sell. Credit sales result in accounts receivable, and longer the credit given to customers higher will be the size of the firm's accounts receivable. When the operations of a firm require higher levels of inventory and more of accounts receivable, the firm necessarily has to arrange for more funds to operate. The source of the funds required to finance inventory and accounts receivable could be short term liabilities such as accounts payable and bank borrowings, long term debt or shareholders' funds. A firm purchase of goods from suppliers may be on cash terms or on credit. The longer the period of credit extended by a firm's suppliers the bigger the size of its accounts payable, and therefore the less the requirement for funding inventory and accounts receivable. The net amount of funds a firm needs for its operations therefore primarily depends on inventory plus accounts receivable minus accounts payable, which is working capital requirements. Higher funding requirement implies higher cost of funds and lower profit performance.

Using basic accounting identities (Zietlow, Maness \& Hill, 2013) working capital can be disaggregated as

$$
\begin{aligned}
W C=C A-C L & \\
& =(C A S H+I N V T+R E C V B L S)-C L
\end{aligned}
$$




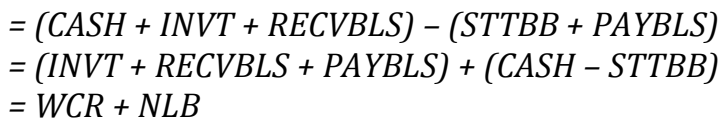

(5)

where WC is working capital, CA is current assets, CL is current liabilities, CASH is cash and bank balances held by the firm, INVT is inventory investment, RECVBLS is accounts receivables and prepayments, STTBB is short term bank and non bank borrowings, and PAYBLS is accounts payables and accruals. WCR is working capital requirements and NLB is net liquid balance.

The disaggregation of the working capital allows us to reason that increase in working capital requirements of a firm can lead to performance constraints if there is an increase in inventory investments and increase in accounts receivables. However increase in cash holding by the firm cannot result in financing constraints, as the higher levels of cash can always be used to finance the increasing sales growth or to repay debt. Increase is working capital due to increase in cash (but without increases in inventory and receivables) cannot lead to financing constraints as the available cash can be used to finance additional working capital requirements. The metrics therefore which need to be empirically examined while looking at the question of impact of working capital on performance ( based on the methodology suggested by Bushman, Smith \& Zang (2011) are inventory investment, investment in accounts receivables by firms and funding from accounts payables. Using this conceptual framework, we expect that poorly performing firms will exhibit higher levels of inventory, higher levels of accounts receivable, and will have lower levels of accounts payable.

\section{Literature Review}

Traditionally corporate finance literature has focused on the impact of long term assets ( fixed assets) on corporate performance, although a major part of the left side of the balance sheet consists of investment in short term assets -inventory and accounts receivable (Martinez \& Garcia, 2006). One of the seminal papers in the area of working capital efficiency is the study by Richards and Laughlin (1980) which introduced the concept of cash conversion cycle (CCC) and operating cycle. Operating cycle is defined as the number of days required for a firm to convert inventory into finished goods, and finally selling and collecting the accounts receivables. Operating cycle minus the number of days taken to pay for inventory purchases is the CCC which is defined in number of days. An alternate method of measuring working capital efficiency is to use financial ratios based on the components of working capital requirements: inventory to cost of sales ratio, accounts receivable to sales ratio and accounts payable to cost of sales ratio (Maness \& Zietlow (2005). Past studies done in various countries have shown that reducing cash conversion cycle to a reasonable extent, by reducing days inventory held and receivables outstanding, increases firm profitability Smith (1980), Deloof (2003), Shin \& Soenen (1998). However, while reduction in investment in working capital assets improves profitability, it can increase risk due to the likelihood that the firm may not have enough inventory when needed and the possibility that some customers may not buy unless they get enough trade credit (Martinez \& Garcia, 2006).

While empirically estimating the impact of working capital practices on firm performance, endogeneity can be a problem (Deloof, 2003), because while lower inventory and lower account receivables improves profitability, at the same a firm experiencing profitability problems due to competition, market pressures or other reasons, may decide to reduce inventory and reduce receivables so as to reduce interest expenses. This raises the question whether lower profits leads to lower working capital or the other way round. Martinez \& Garcia (2006) in a study covering 8,872 firms using techniques which are robust to the endogeneity problem find that reducing the firm's number of days of accounts receivable and inventories adds to the firm's value. Some studies find that industry classification is important in understanding the relationship between working capital and profitability. Importance of efficient working capital management practices for small and medium sized firms has been another area of empirical investigation (Peel \& Wilson, 1996; Martinez \& Garcia, 2006).

Recent studies done in several countries such as United Kingdom, Singapore, Greece, Malaysia, Turkey and Sri Lanka find that profitability can be improved by shortening receivable conversion period and inventory conversion period (Thuvarakan, 2013; Rathiranee, 2014; Mansoori \& Mohammed, 2012; Azhar \& Noriza, 2010; Sen \& Oruc, 2009 \& Lazaridis \& Dimitrios, 2006). While earlier studies have looked at data from many countries across the world this paper is a first of its kind. The present study covers both large and medium sized firms. To cope with the effect of size we use total assets as a control variable. 
Table 1: Definitions

\begin{tabular}{ll}
\hline PBTTA & Pre-tax return on assets \\
INVCGSAVG & Average inventory to cost of goods sold ratio \\
RECSLSAVG & Average receivables to sales ratio \\
PYBLCGSAVG & Average payables to cost of goods sold ratio \\
GPM & Gross profit margin \\
AGE & Age of the firm \\
TA & Total asset, a proxy for size \\
\hline
\end{tabular}

\section{Methodology and Data}

Corporate financial performance can be measured using variety indicators such as net income, operating profits, return on equity, return on assets, economic value added etc. Of these return on equity and return on assets are most suitable as the study is a cross section study cutting across firms operating in different countries. Return on assets is a superior measure compared to return on equity for the purpose of this study. Return on equity depends on the capital structure of the firm and as such working capital management practices have little or no influence on capital structure decisions. Return on assets directly measures the impact of working capital on corporate profitability, and is not influenced by debt structure of the firm. Since tax rates can vary from firm to firm and from country to country, pre-tax return on assets is the preferred measure to assess corporate financial performance. In this study pre-tax return on assets (ROA defined as profit before tax divided by total assets), is used to measure corporate financial performance.

Working capital requirement (WCR) by definition is inventory plus account receivables minus accounts payables. However when doing inter-temporal analysis across different years or cross section analysis across different companies there is a need to standardize the measure to overcome size effects. While some studies (Deloof, 2003) use inventory holding days, receivables conversion days or payable outstanding days as measures, this study uses a different set of WCR measures: average inventory to cost of goods sold, average receivables to sales and average payables to cost of goods using the methodology suggested by Zietlow, Maness \& Hill (2013). These measures are financial ratios rather than being days and are easier to use from an interpretation point of view. Empirical analysis is based on 2012 end of year financial statement data of 153 large manufacturing firms operating in the Gulf Cooperation Council (GCC) countries.

\section{Estimation Techniques}

Robustness Checks, Heteroscedasticity and Robust Least Squares Method: Econometric methods such as the regression techniques are the first choice for empirically investigating the relationship between firm profitability and WCR components - inventory, accounts receivable and accounts payable. However, while using cross section data the standard OLS (ordinary least squares) method of estimation can lead to problems (Gujarati, 2003). Since the data for the present study is drawn from 153 large manufacturing firms across the GCC, it is cross sectional in nature. One of the assumptions of the OLS regression model is that there is no heteroscedasticity. There is a strong possibility that cross section data suffers from problems of heteroscedasticity. When heteroscedasticity is present, statistical tests (such as t-test) of significance that assume that modelling errors are uncorrelated and normally distributed become invalid, because standard errors of coefficients tend to be biased. Inferences based on biased standard errors are therefore suspect.

Cross regression techniques which take care of the problem of heteroscedasticity are required to analyse data of this type In this study estimation was done using White's heteroscedasticity-consistent standard errors (also known as robust standard errors) Gujarati (2003) \& Greene (2000). Further to take care of the problem of outliers which was noticed during analysis, the study uses the Robust Least Squares estimation method (Andersen, 2008). OLS estimates are highly sensitive to outliers (that is they are not robust against outliers). Least squares estimation is inefficient and tends to be biased. Robust estimation techniques such as Huber's M-estimation method provide automatic ways of detecting, down weighting (or removing), and flagging outliers. The study used the E-Views software for purpose of robust estimation. 


\section{Results}

For the purpose of analysis two types of regression analysis was attempted. The first is least squares with white heteroskedasticity consistent estimators. This was down with purpose of controlling for possible problems posed by heteroskedasticity. The results show that R squared and adjusted R squared are good and that average receivables, gross profit margin and age are statistically important variables explaining behaviour of ratio of profit before tax to total assets, that is pre-tax ROA. Jarque-Bera test value at 6.44 also indicates that residual errors are not normally distributed. Plots of the data show that there could be problem of outliers in the data set in the regressors (independent variables).

Table 2: Dependent Variable: PBTTA

\section{Method: Least Squares Regression}

White heteroskedasticity-consistent standard errors \& covariance

\begin{tabular}{lll} 
Variable & Coefficient \\
C & -0.00316 & \\
INVCGSAVG & -0.02039 & \\
RECSLSAVG & -0.18109 & $*$ \\
PYBLCGSAVG & -0.00084 & \\
GPM & $0.246268 *$ \\
AGE & $0.001328 *$ \\
TA & $-1.96 \mathrm{E}-$ & \\
& 09 & \\
R-squared & & \\
Adjusted R-squared & 0.415242 & \\
JB & 0.381506 \\
\hline
\end{tabular}

* significant at $1 \%$ level

Therefore "Robust Least Squares" technique was adopted to take care of outliers in the data. Of the three different methods of robust least squares, that M-estimation, S-estimation and MM estimation, in this paper we used the S-estimation which is specifically designed for outliers in regressors. In the robust regression problem of heteroskedasticity is handled using Huber standard errors.

The results obtained are same as those of the White - adjusted least square procedure. Again we found that average receivables, gross profit margin and age are the significant variables explaining the behaviour profits (pbtta). Average inventory levels and average payables had no influence on firm performance. The negative sign indicates that higher the average receivables lower is the pre tax ROA. Further Jarque-Bera test for normality indicates that the errors are normally distributed indicating that our model does not suffer from mis-specification errors. (JB at 5.8 is less than the chi square value). Gross profit margins and size are control variables in the above model. They are statistically significant as expected. The above regression estimates imply that inventory does not impact pre-tax return on assets. This finding is at variance with the results obtained by other studies Deloof (2003), Martinez \& Garcia (2006), Sen \& Oruc (2009), Lazaridis \& Dimitrios (2006). To understand this result, a deeper understanding of the workings of companies operating in the Gulf Cooperation countries (GCC) is required and this was attempted as part of this study. Interest costs are very low for GCC manufacturing companies and many are supported by soft loans from their respective governments. Companies can afford to maintain high levels of inventory without the worry of higher costs. High levels of inventory therefore do not have much of an impact on the profits and on pre-tax return on assets. 
Table 3: Dependent Variable: PBTTA

\begin{tabular}{ll}
\hline Method: Robust Least Squares Regression & \\
Method: S-estimation & \\
Huber Type I Standard Errors \& Covariance & \\
\hline Variable & Coefficient \\
C & -0.00963 \\
INVCGSAVG & -0.00788 \\
RECSLSAVG & $-0.19909 *$ \\
PYBLCGSAVG & -0.00095 \\
GPM & $0.206834 *$ \\
AGE & $0.001684 *$ \\
TA & $7.75 \mathrm{E}-10$ \\
& Robust Statistics \\
R-squared & 0.271762 \\
Adjusted R-squared & 0.229749 \\
Rn-squared statistic & 67.74606 \\
JB & 5.86 \\
\hline
\end{tabular}

* significant at $1 \%$ level

The regression results reported above show that higher levels of accounts receivables have a strong negative impact on pre-tax return on assets that is on profitability of GCC companies. This result is very much in agreement with what has been reported in earlier studies done in other countries. However, as mentioned just now interest costs are very low for GCC manufacturing companies in spite of heavy use of debt because of low interest rates and soft loan support form governments. The negative impact of accounts receivable on profitability can be explained not through interest cost argument, but because of bad debts associated with accounts receivable. It is a known fact that companies giving more credit to customers typically suffer from higher levels of bad debt. Profitability of GCC manufacturing firms is negatively impacted by higher levels of accounts receivable because it proxy's for bad debt and not because it proxy's for higher interest cost.

\section{Conclusion}

The main findings of the study are that corporate financial performance of GCC manufacturing companies, as measured by pre-tax return on assets, is strongly influenced by average accounts receivable levels after adjusting for the influence of control variables. Inventory levels had no impact on financial performance. Similarly payables had no effect on financial performance, although in theory higher levels of payables should lead to better profitability. Average accounts receivables have a strongly significant negative influence on performance of GCC manufacturing companies. Lower investment in accounts receivables directly results in better profits along with less of assets, thus leading to better pre-tax return on assets. The results imply that a typical GCC manufacturing company can improve profitability by reducing the level of accounts receivable and by better bad debt management. The paper therefore concludes that better accounts receivable management will be beneficial from a performance point of view.

\section{References}

Andersen, R. (2008). Modern Methods for Robust Regression. Sage University Paper Series on Quantitative Applications in the Social Sciences, 07-152.

Azhar, N. \& Noriza, M. (2010). Working Capital Management: The Effect of Market Valuation and Profitability in Malaysia. International Journal of Business and Management, 5(11), 140-147.

Bushman, R. M., Smith, A. J. \& Zhang, F. (2011). Investment Cash Flow Sensitivities Really Reflect Related Investment Decisions (August 5, 2011). Available at SSRN: http://ssrn.com/abstract=842085 or http://dx.doi.org/10.2139/ssrn.842085

Deloof, M. (2003). Does Working Capital Management Affect Profitability of Belgian Firms? Journal of Business Finance and Accounting, 30, 573-587.

Greene, W. (2000). Econometric Analysis, Fourth Edition, Prentice Hall. 
Gujarati, D. N. (2003). Basic Econometrics, Fourth Edition, McGraw-Hill.

Heath, L. C. (1989). Is Working Capital Really Working? Journal of Accountancy, 3, 55-62.

Maness, T. S. \& Zietlow, J. (2005). Short Term Financial Management, 3rd edition, South Western.

Petersen, M. A. \& Rajan, R. G. (1997). Trade Credit: Theories and Evidence. Review of Financial Studies, 10, 661-691.

Rathiranee, Y. (2014). Working Capital Management and its Impact on Firms' Financial Performance: An Analysis of Trading Firms Sri Lanka. Available at SSRN: http://ssrn.com/abstract=2444311

Richards, V. \& Laughlin, E. (1980). A cash conversion cycle approach to liquidity analysis, Financial Management, 32-38

Lazaridis, I. \& Dimitrios, T. (2006). Relationship between Working Capital Management and Profitability of Listed Companies in the Athens Stock Exchange. Journal of Financial Management and Analysis, 19(1), January-June 2006. Available at SSRN: http://ssrn.com/abstract=931591

Mansoori, E. \& Muhammad, D. J. (2012). The Effect of Working Capital Management on Firm's Profitability: Evidence from Singapore (March 6, 2012). Interdisciplinary Journal of Contemporary Research in Business, 4(5).

Martínez-Solano, P. \& García-Teruel, P. J. (2006). Effects of Working Capital Management on SME Profitability. April 2006. Available at SSRN: http://ssrn.com/abstract $=894865$ orhttp://dx.doi.org/10.2139/ssrn.894865.

Peel, M. \& Wilson, N. (1996). Working Capital and Financial Management Practices In The Small Firm Sector. International Small Business Journal, 14(2), 52-68.

Sen, M. \& Oruc, E. (2009). Relationship between Efficiency Level of Working Capital Management and Return on Total Assets in Ise. International Journal of Business and Management, 4 (10, 109-114.

Smith, K. (1980). Profitability versus Liquidity Tradeoffs in Working Capital Management. Readings on the Management of Working Capital. Ed. K.V. Smith, West Publishing Company, 549-562.

Shin, H. H. \& Soenen, L. (1998). Efficiency of Working Capital and Corporate Profitability. Financial Practice and Education, 8, 37-45.

Thuvarakan, S. (2013). Impact of Working Capital Management on Profitability in UK Manufacturing Industry (September 27, 2013). Available at SSRN: http://ssrn.com/abstract=2345804 orhttp://dx.doi.org/10.2139/ssrn.2345804

Zietlow, J., Maness, T. S. \& Hill, M. (2013). Short Term Financial Management, $4^{\text {th }}$ edition, Cognella. 